С. И. Сулимов, И. В. Черниговских. Взаимодействие внутреннего и внешнего варварства в моменты кризиса цивилизации

Научная статья

УДК : 130.2

DOI: $10.18101 / 1994-0866-2021-2-17-26$

\title{
ВЗАИМОДЕЙСТВИЕ ВНУТРЕННЕГО И ВНЕШНЕГО ВАРВАРСТВА В МОМЕНТЫ КРИЗИСА ЦИВИЛИЗАЦИИ
}

\author{
(C) Сулимов Станислав Игоревич \\ кандидат философских наук, доцент, \\ Воронежский государственный университет \\ Россия, 394018, г. Воронеж, Университетская площадь, 1 \\ sta-sulimov@ya.ru
}

\section{(C) Черниговских Игорь Васильевич}

кандидат философских наук, доцент,

Воронежский государственный университет инженерных технологий

Россия, 394036, г. Воронеж, пр-т Революции, 19

igrchernigovskix@rambler.ru

\begin{abstract}
Аннотация. Данная работа посвящена анализу взаимодействия цивилизованного и варварского обществ, которые являются неизбежным политико-культурным процессом на протяжении всей мировой истории. Авторы полагают, что технологический и политический уровень развития цивилизованного общества делает его неуязвимым для внешней варварской агрессии до тех пор, пока сохраняется духовное единство цивилизации. Духовный кризис же ведет к возникновению и расширению рядов варваров внутренних - граждан, в социальном плане принадлежащих к цивилизации, но не разделяющих ее ценности. Именно они делают общество беззащитным перед внешними врагами, так как используют политические и экономические механизмы цивилизации лишь в личных и партикулярных целях. Понятия «цивилизация» и «варварство» авторы определяют, ссылаясь на исследования отечественного философа Н. В. Мотрошиловой, а фактический материал заимствован ими из трудов западноевропейских и восточных историков.

Ключевые слова: цивилизация, варварство, внешние и внутренние варвары, духовный кризис контркультура, культурное ренегатство, Римская империя, императорский Китай, «Артхашастра», «темные» века
\end{abstract}

\section{Для цитирования}

Сулимов С. И., Черниговских И. В. Взаимодействие внутреннего и внешнего варварства в моменты кризиса цивилизации // Вестник Бурятского государственного университета. Философия. 2021. Вып. 2. С. 17-26.

Современный исторический этап характеризуется завершением установления в мире глобальной цивилизации: единые экономические структуры и правовые принципы охватывают все регионы и государства, все общества соседствуют друг с другом посредством сети Интернет и сотрудничают благодаря миграции капиталов и трудовых ресурсов. Американский философ И. Валлерстайн убедительно доказал, что формирование единой мировой системы, структурировавшей мировое сообщество по принципу «центр - периферия» уже завершилось [5; с. 86]. Но ни для кого не является секретом разница в образовательном уровне и 
круге интересов представителей различных стран, культур и регионов. Жители Западной Европы и Северной Америки, имеющие дело с мигрантами из стран «третьего мира», нередко видят в них варваров, угрозу для самого существования западной цивилизации, легшей в основу глобализации [4; с. 41]. Так ли это? Мигранты, прибывшие в западные страны в поисках работы и высокой зарплаты, действительно ли представляют собой угрозу для местной цивилизации? А если посмотреть более глобально, то опасны ли жители мирового «юга» для мирового порядка, созданного мировыми «северянами»? Это были бы вопросы без ответов, если бы не обилие аналогичных прецедентов в прошлом: глобальная мировая система является далеко не первой попыткой подчинить весь известный мир единым политическим, экономическим и правовым принципам. История знает, по меньшей мере, два таких удачных социально-политических эксперимента (pax romana и dap aль-ислам) и немало менее удачных попыток. Поэтому взаимодействие цивилизации с окружающими ее и в культурном отношении иными «варварскими» обществами представляет собой классику исторического процесса. В данной работе мы обратимся к этому фактическому материалу, чтобы определить, при каких условиях варвары представляют для цивилизованного общества угрозу, а при каких обстоятельствах они для цивилизации безопасны.

Прежде чем говорить о соседстве и противостоянии цивилизации с варварскими обществами, необходимо как-то охарактеризовать понятия «цивилизация» и «варварство». Ведь ни один народ никогда не именовал себя варварским. Это название придумывают и пускают в оборот цивилизованные соседи, которые, в свою очередь, не объясняют, почему они сами варварами не являются. Поэтому разграничить цивилизацию и варварство можно лишь при взгляде со стороны. Отечественный исследователь Н. В. Мотрошилова предложила считать основным критерием цивилизованности того или иного общества доминирование в его жизни социально-исторических, а не природно-биологических факторов. Например, цивилизованное общество не бежит от засухи, как это могли бы сделать средневековые кочевники, а предпринимает ирригационные работы для того, чтобы изменение природных условий не повлияло на его социальноэкономический климат [10; с. 22]. Цивилизованное общество имеет много важных черт, среди которых совершенствующееся материальное производство, возрастающее вмешательство общества в природные процессы, углубляющееся разделение труда, стремление к ненасильственному решению проблем и т. д. Главными отличительными чертами цивилизованного человека Н. В. Мотрошилова считает трудолюбие, правосознание и стремление к материальному комфорту. Мы можем предположить, что для цивилизованного человека характерно не столько трудолюбие, понимаемое как любовь к самому трудовому процессу (например, монашеское трудничество), сколько предельно рационализированное отношение к гражданскому и воинскому труду. Гражданин цивилизации трудится тогда, когда лично ему это необходимо для достижения каких-то личных целей — не больше и не меньше.

Ключевым критерием варварского общества Н. В. Мотрошилова считает доминирование природно-биологических факторов над социальноисторическими. Это не означает, что варвары полностью детерминированы при- 
С. И. Сулимов, И. В. Черниговских. Взаимодействие внутреннего и внешнего варварства в моменты кризиса цивилизации

родой, более того, любое варварское общество содержит в зачаточном виде тот потенциал, развитие которого приведет к достижению цивилизованного состояния. Варварам знакомы и разделение труда, и материальное производство, уровень которого не всегда низок, и правовое регулирование социальных процессов; просто все эти общественные механизмы в их обществе не так ярко выражены, как у описывающих их цивилизованных народов. К примеру, датский историк В. Грёнбек отмечает такую особенность древних германцев и скандинавов, как стремление воспроизводить свой оригинальный социально-правовой порядок на любой новой родине и желание соблюдать только собственные законы, но никак не жить в условиях анархии [6, с. 14]. Можно сказать, что «варвары» существуют лишь в летописях и заметках цивилизованных соседей, а сами по себе эти народы и племена либо очень молоды, либо их культурная картина мира покоится на принципиально иных основаниях, нежели у изучающих их жизнь исследователей. Если говорить упрощенно, то варварство может быть лишь относительным. К примеру, Цезарь и Тацит считали кельтов и германцев дикарями, но по сравнению с австралийскими аборигенами той же эпохи свебы или хатты показались бы носителями высокой культуры и цивилизованного образа жизни.

Н. В. Мотрошилова делает важную оговорку, что варварство бывает как внешним по отношению к цивилизации, так и внутренним. Внутреннее варварство появляется в цивилизованном обществе и проявляется тем ярче, чем слабее становятся сдерживающие политические и правовые механизмы этого общества. Внутренний варвар - это не пришелец из диких земель, а духовнонравственный отступник, знакомый с нормами цивилизованной жизни и намеренно их отвергающий в пользу своекорыстных интересов. В дальнейшем мы не раз увидим проявления этой позиции в самые неподходящие для цивилизованного общества моменты.

Различие между внутренним и внешним варварством станет заметно, если мы обратимся к пониманию основ культуры, предложенному отечественным исследователем В. П. Римским: «Архетипы можно рассматривать как чистые формы, формы идеального, связывающие человека с глубинными структурами мироздания. Потому важную роль в формировании сознания играют природные характеристики человеческого бытия: существование человека в определенной природно-экологической среде и в «плазме» этносов как природно-исторических, социально-биологических образований. Именно на данной глубине человеческого бытия и формируются архетипы национального менталитета и самосознания, проявляющиеся в этнической психологии (сознательные и бессознательные импульсы) и стереотипах этнического поведения» [14, с. 36]. Архетипы, лежащие в основе культуры внешнего по отношению к цивилизации варвара, либо не получили еще полного социально-политического выражения, что препятствует их пониманию цивилизованными наблюдателями, либо настолько оригинальны, что наблюдатель не может найти в своей культуре подходящую аналогию. Внутренний же, порожденный самой цивилизацией варвар отделен от архетипов родной культуры, он - духовно чужой у себя же на родине. К таким внутренним варварам мы можем отнести адептов тайных обществ и сект хилиастической направленности, подпольных антиправительственных кружков и организаций, а также 
коррумпированных чиновников и крупных предпринимателей, ориентированных исключительно на личные и партикулярные интересы. Обычно внутреннее варварство выходит на историческую сцену либо во время заката цивилизованного общества (когда его культурный потенциал полностью реализован и уже никого не вдохновляет), либо при включении в орбиту цивилизации развитого, но культурно чуждого народа.

Очень важно отметить, что все известные истории автохтонные цивилизации четко отграничивают внешних варваров от своего мира и не считают последних равными себе. Так, греческое слово «варвар» имеет аналог в индийских языках — «млеччха» — и точно так же, как греческих, термин подражает чуждой неразборчивой речи [8, с. 257]. В средневековом Китае под варварами понимали преимущественно кочевников, которых китайцы воспринимали как звероподобных и агрессивных чужаков. При этом национальная и этническая специфика не принималась в расчет ни индийцами, ни китайцами, ни греками: варварство, на их взгляд, было именно культурной характеристикой того или иного народа. Например, греки вполне допускали эллинизацию жителей Леванта и Северного Причерноморья, римляне проводили романизацию кельтов, а в китайской придворной академии нередко получали образование дети знатных степняков.

Также важно отметить, что, впервые встречаясь друг с другом, представители различных цивилизаций сначала навешивают друг на друга ярлыки «варваров», но по мере знакомства с достижениями друг друга быстро отходят от такой практики и переходят к взаимному уважению. Так, римляне после знакомства с парфянами и персами стали считать их равными себе, замечая аналогии между режимами императора и шахиншаха. Индийцы первоначально восприняли вторгнувшихся в Пенджаб македонцев как типичных «млеччха», но по мере знакомства с греческой культурой охотно пошли на контакт, даже выделив западных пришельцев из числа варваров отдельным названием «явана» («ионийцы»). Китайская империя, считая варварами кочевников, на равных вела дела с Константинополем и мусульманскими государствами Средней Азии. То есть любые незнакомцы сначала вносятся цивилизованным обществом в категорию «варваров», но затем, по мере обнаружения культурных аналогий, обретают собственные названия и равный статус (если не де юре, то де факто). И, наоборот, если таких аналогий незаметно или социально-политический и экономический уровень позволяет смотреть на соседей свысока, то они автоматически считаются варварами, и отношение к ним всегда будет пренебрежительным или снисходительным, без различия их племенной или культурной принадлежности. Так, для римлян одинаково варварами были арабы, кельты, кочевники и германцы, имеющие между собой только те общие черты, что все они не похожи на римлян и греков и уступают последним в экономическом и техническом отношениях.

Выше мы вслед за Н. М. Мотрошиловой отметили, что для цивилизованного общества характерны рационализация труда и стремление к материальному комфорту. Следовательно, любая цивилизация уделяет первостепенное внимание вопросам познания, освоения и практического использования природы и ее законов, что почти всегда обеспечивает цивилизованному обществу более высокий уровень развития техники, чем у его варварских соседей. В превосходстве техно- 
С. И. Сулимов, И. В. Черниговских. Взаимодействие внутреннего и внешнего варварства в моменты кризиса цивилизации

логий коренится моральное право считать варваров «ущербными», «неразумными» или даже «звероподобными». И в этом же техническом превосходстве содержится возможность побеждать варваров на поле боя или хотя бы эффективно пресекать их военную агрессию. Цивилизованное общество очень хорошо умеет защищать свои рубежи от захватчиков хотя бы потому, что знакомо с географией и намечает линии этих рубежей заранее, в наиболее удобных для обороны местах. Можно сказать, что цивилизация неразрывно связана с фортификацией. Вот как описывает создание и усовершенствование римского лимеса немецкий историк Г. Дельбрюк: «Первый пограничный вал состоял из сплетенных оборонительных щитов (vineae). При Адриане вместо них появились палисадные ограждения, а через несколько поколений палисады были дополнены и заменены валом и рвом. Приблизительно в начале III столетия к этим укреплениям прибавилась последняя часть, а именно высокая каменная стена, расположенная на участке к северу от Дуная, на ретской границе» [7, с. 136].

Не менее впечатляют аналогичные укрепления китайской цивилизации: «Валы, сооруженные вокруг шанских городов, представляют собой ранние китайские укрепления. Вал строили, утрамбовывая землю деревянными молотами, пока она не становилась твердой, как кирпич. Вокруг Ао валы были толщиной 60 футов (около 18,3 м) в основании и высотой 25 футов (около 7,5 м). ...Впоследствии оборона была усилена благодаря изобретению катапульт, которые устанавливали на стенах» [13, с. 53]. Великая китайская стена представляет собой грандиозный лимес, при помощи которого цивилизация обороняла свои границы от «северных варваров».

Индийская цивилизация тоже обороняла свои территории при помощи системы крепостей. Вот как описывает индийскую фортификацию советский историк К. З. Ашрафян: «Кроме укрепленных городов существовало большое количество небольших крепостей — тхана. В отличие от мощных фортификационных сооружений, защищавших города и известных под названием «хисар», «кале» (кила) и «кот», тхана строились на границах государства или наместничеств, у речных переправ и горных проходов, а также просто на дорогах. Тхана служили для борьбы с мятежными князьями и племенами, для изъятия у них дани, расширения владений султанов за счет земель непокорных феодалов и независимых племен или этнографических групп» [3, с. 87-88].

Но цивилизованное общество, вступая в военную конфронтацию с варварами, далеко не всегда предпочитало отсиживаться за неприступными стенами. Например, римские легионы I в. до н. э. - I н. э. почти в каждом бою наносили поражения кельтам и германцам, что совсем неудивительно, если учитывать разноплановую боевую подготовку легионеров и слаженное функционирование родов войск. Построенные по всем правилам военной инженерии, римские полевые лагеря оказывались для варваров неприступными, а стандартизованное вооружение легионеров позволяло римскому строю отражать даже самые неистовые атаки германцев и кельтов. То же самое можно сказать о войске императорского Китая, воины также были знакомы с различными видами боевого и походного строя и строительством укрепленных лагерей, а в бою со степными конными лучниками мастерски применяли арбалеты. Так, степные варвары неоднократно 
терпели сокрушительные поражения от императорской армии, в которой умело взаимодействовали конница и пехота: в 121 г. до н. э. китайский полководец Хо Цюйбин разгромил гуннов, прекратив их набеги на долгих 18 лет, а в 657 г. н. э. имперский принц Ли Шиминь фактически уничтожил орду кочевниковтюрков в битве у озера Иссык-Куль [13, с. 106]. Кроме того, цивилизованное общество, рационально действуя на упреждение, всегда располагает развитой разведкой и контрразведкой. Если римские «спецслужбы» полагались на скрытые рейды военных разведчиков в глубину германских лесов и шотландских гор, то китайское военное министерство эпохи Тан располагало особым подразделением, скромно именуемым «Отдел управления окраинами». Сотрудники этой службы не только регистрировали и опрашивали всех прибывающих в Китай иностранцев, но и тайком зарисовывали их портреты, создав, таким образом, подробную картотеку потенциальных шпионов задолго до изобретения фотосъемки [15, c. 227-228]. Индийской цивилизации в открытом противостоянии с варварами повезло меньше: почти все вражеские вторжения в Пенджаб и Бенгалию завершались разгромом индийских войск, но причина этих поражений лежит не в сфере военных технологий. О ней мы скажем ниже, в соответствующем месте нашей работы.

Однако и античный Рим, и Китайская империя стали жертвами варварских народов, в техническом и политическом отношении несопоставимых с этими цивилизациями. Как же это могло случиться? Думается, одна из самых главных причин этого краха заключается в активизации внутреннего варварства. Каков же обобщенный портрет этого могильщика развитых обществ? Обычно это человек, сформировавшийся на лоне цивилизации в момент ее духовного кризиса, возможно, образованный и эрудированный, но никак не связанный с духовными основами породившего его общества. Это либо духовный ренегат, ориентирующийся на контркультуру, либо приспособленец, ищущий всегда и во всем свою личную выгоду. Суть внутреннего варвара красноречиво описал французский исследователь О. Кошен: «Этот философский дикарь - весьма своеобразная личность: вообразите себе француза XVIII века, который располагает всеми плодами цивилизации своего времени, всей ее материальной частью: культурой, воспитанием, познаниями и вкусом, но не имеет никаких живых побуждений инстинктов, верований, которые все это создали, вдохнули жизнь в эти формы, дали основания этим обычаям, применение этим средствам; поставьте его внезапно перед этим миром, в котором ему доступно все, кроме главного - смысла; он будет все видеть и все знать, но не поймет ничего» [9, с. 36]. Как только таких образованных и даже высокопоставленных «дикарей» становится много, количество переходит в качество: вслед за духовным кризисом общество постигают кризисы политический и экономический. Ведь созданная ценой общих усилий предельно рационализированная, сложная и выверенная государственная машина не может эффективно функционировать, если ее чиновники воспринимают ответственные должности лишь как способ личного обогащения, крупные предприниматели «забывают» платить налоги, а трудящееся население ежедневно ощущает свое бесправие. В такой обстановке противопоставление цивилизации внешним варварам прекращается, потому что исчезает распознавание своих и 
С. И. Сулимов, И. В. Черниговских. Взаимодействие внутреннего и внешнего варварства в моменты кризиса цивилизации

чужих. Живущий за лимесом германец или кочевник не кажется внутренним варварам таким опасным, как собственный сосед, мешающий осуществлять незаконные экономические аферы и административные гешефты. Поэтому все ресурсы цивилизации и созданные ею военные и политические институты становятся лишь инструментами, при помощи которых внутренние варвары борются между собой. А внешние варвары получают замечательную возможность безнаказанно грабить и присваивать плодородные и возделанные земли.

Обратимся к историческим примерам. Германские варвары не могли прорвать римский лимес до тех пор, пока его охраняли легионы. Но стоило легионам вступить в борьбу друг с другом ради подачек от очередного «солдатского» императора, как граница осталась без защиты. Укрепления, рассчитанные на оборону регулярной армией, оказались совершенно бесполезными для мирных жителей. В то время как легионы самозабвенно сражались друг с другом и пополняли свои средства путем поборов с мирного населения, варвары просто-напросто проходили через границу, которую больше никто не защищал. Любопытно, что с IV в. н. э. высшие имперские чиновники стали заключать с германцами договоры o «союзе» (faedus), ставя целые племена на довольствие жителей той или иной провинции. Варварские вожди получали военные и гражданские звания, практически ничего не делая для государства, но оказывая услуги отдельным сановникам. Получалось, что действие законов цивилизованного общества, согласно которым нужно трудиться, повиноваться и платить налоги, распространяется только на гражданское население, а дикие и вооруженные чужаки по умолчанию оказываются в привилегированном положении. Немудрено, что отношение простонародья к государству быстро становилось враждебным. Так, ливийский историк М. С. Айюб описывает движение циркумцеллионов, охватившее североафриканские провинции Римской империи, в доктрине которого перемешались донатистское христианство и берберский сепаратизм, а в деятельности - криминальные и военные методы противостояния империи и официальной церкви $[1$, c. 78].

Если же мы посмотрим, как взаимодействовали с внешними чужаками внутренние варвары Китая, то увидим похожую картину, только с местной спецификой. Например, в моменты внутренней борьбы у китайских чиновников и полководцев всегда возникало желание пропустить «северных варваров» через пограничные укрепления и натравить их на своих политических противников. Например, в начале IV в. империя Цзинь столкнулась с вооруженным выступлением в области Лянчжоу, вождь которого Шуцзинэн озвучивал сепаратистские лозунги. После того, как императорские войска продемонстрировали свою неэффективность, правительство решило обратиться за помощью к гуннскому принцу Лю Юаньхаю, получившему образование в Лояне, но пользовавшемуся среди кочевников непререкаемым авторитетом. Высшие сановники пригласили кочевого правителя захватить мятежную область и по своему усмотрению расправиться с ее населением. Китайский историк Фан Сюаньлин подробно описывает придворное совещание, на котором решался вопрос интервенции в пределы империи: «Ли Си резко возразил: "Если мы используем отвагу сюнну и умение Лю Юаньхая командовать войсками для того, чтобы распространить величие императора, 
то можно ли говорить о неполном искоренении бедствий!". Кун Сюнь ответил: "Если Лю Юаньхай сможет усмирить область Лянчжоу и обезглавить Шуцзинэна, боюсь, именно тогда в области Лянчжоу и возникнут затруднения. Ведь дракон, попавший в дождевые тучи, уже не тот, что когда-то жил в пруду"» [16, с. 34]. Степняк все же был приглашен в Китай и наделен чрезвычайными полномочиями, что закономерно позволило ему начать собственную игру. В 308 г. Лю Юаньхай провозгласил себя императором, а в 311 г. гунны захватили Лоян. Впрочем, для китайской цивилизации такие натравливания варваров на собственный народ вовсе не являются экзотикой: в XIII в., когда монголы атаковали северный Китай, южная династия Сун охотно оказывала им военную и дипломатическую поддержку, а в XVII в. имперский полководец У Саньгуй открыл ворота Великой стены кочевникам князя Доргуня, тем самым положив начало почти трехвековому господству маньчжуров в Китае.

Если посмотреть на аналогичный коллаборационизм в Древней и средневековой Индии, то в данной цивилизации сотрудничество с млеччха и натравливание их на соотечественников имеет теоретическое обоснование. Книга «Артхашастра» (IV в. до н. э.) представляет собой памятник индийской социальнофилософской мысли, и ее автор, брахман Каутилья, настаивает на том, что ближайшие соседи - это всегда естественные враги. Главная рекомендация «Артхашастры» заключается в постоянном стравливании ближних и дальних соседей и в заключении союза с чужаками против нелояльных короне аристократов [2, с. 182-183]. Результатом такого руководства стала повторяющаяся из века в век поддержка, которую оказывали всем внешним завоевателям индийские раджи, считавшие себя обделенными или притесненными. Таким образом, с точки зрения традиционной индийской политической культуры сотрудничество с варварами - вовсе не предательство, если помогает утвердить собственную власть. Другое дело, что иноземцы, одержав в Индии ряд побед, почти всегда предпочитали остаться на новом месте и править, избавившись от туземного союзника.

Итак, на исторических примерах мы рассмотрели механизм взаимодействия внутреннего и внешнего варварства, приводящий цивилизованное общество к гибели. Какие ключевые моменты этого процесса мы могли бы выделить? Вопервых, это кризисное состояние цивилизации, благодаря которому количество внутренних варваров быстро увеличивается. Кризис этот необязательно носит политический или экономический характер, достаточно и духовного упадка. Ведь если нет прочных духовных ориентиров, то самоотверженное служение обществу и государству теряет смысл. Во-вторых, внутренняя «варваризация» должна обрести всепроникающий характер. Изменники встречаются в цивилизованном обществе на каждом этапе его развития, но пока такие случаи единичны, они воспринимаются как примеры беспринципности и акты индивидуального предательства. Совсем другое дело, когда верность стране, народу и правительству воспринимается как высокопарная метафора всеми слоями цивилизованного населения. Когда каждый житель цивилизованного общества думает только о собственной выгоде, военные и гражданские технологии, некогда обеспечивавшие превосходство цивилизации над варварством, быстро приходят в упадок или попросту не используются. К примеру, от крепостных стен не будет никакого 
С. И. Сулимов, И. В. Черниговских. Взаимодействие внутреннего и внешнего варварства в моменты кризиса цивилизации

толку, если комендант форта за умеренную плату откроет ворота противнику. Среди равных ему по рангу соотечественников такой ренегат прослывет не предателем, а деловым человеком, по-настоящему «умеющим жить».

Зададимся вопросом «Каково соотношение внутреннего и внешнего варварства в современном мире?». Думается, оно почти такое же, каким было в Римской империи IV в. н. э. и Китайской империи Цзинь периода Троецарствия (220-280 гг. н. э.). Не секрет ведь, что мигранты, которых едва не миллионами приглашают западноевропейские и североамериканские правительства, выгодны только крупным предпринимателям в качестве дешевой рабочей силы и политикам-популистам в качестве безотказного электората. При этом образовательный уровень мигрантов нередко оказывается очень низким, а их культурная специфика не позволяет им быстро адаптироваться к чуждой цивилизации [12, с. 47]. Проще говоря, для большинства местного населения эти люди в лучшем случае бесполезны, а в худшем - враждебны. Но, как мы установили, внутренним варварам нет дела до соотечественников. Современные западноевропейские и североамериканские страны рискуют повторить судьбу цивилизаций, пытавшихся создать глобальный мир в минувшие эпохи.

\section{Литература}

1. Айюб М. С. Гарама (из истории ливийской цивилизации) // Гарамантида (африканская Атлантида). Москва: Восточная литература РАН, 1994. С. 20-101. Текст: непосредственный.

2. Александров Г. Ф. Очерк истории социальных идей в Древней Индии. Минск: Изд-во АН БССР, 1959. 301 с. Текст: непосредственный.

3. Ашрафян К. 3. Средневековый город Индии XIII - середины XVIII века (проблемы экономической и социальной истории). Москва: Наука, 1983. 231 с. Текст: непосредственный.

4. Бьюкенен П. Дж. На краю гибели. Москва: Изд-во АСТ, 2008. 349 с. Текст: непосредственный.

5. Валлерстайн И. Миросистемный анализ: введение. Москва: Территория будущего, 2006. 248 с. Текст: непосредственный.

6. Грёнбек В. Эпоха викингов. Мир богов и мир людей в мифах северных германцев. Москва: Центрполиграф, 2019. 607 с. Текст: непосредственный.

7. Дельбрюк Г. История военного искусства в рамках политической истории: в 7 томах. Т. 2: Германцы. Москва: Воениздат, 1937. 400 с. Текст: непосредственный.

8. Кей Д. История Индии. Москва: Изд-во АСТ, 2011. 761 с. Текст: непосредственный.

9. Кошен О. Малый народ и революция. Москва: Айрис-Пресс, 2004. 296 с. Текст: непосредственный.

10. Мотрошилова Н. В. Цивилизация и варварство в эпоху глобальных кризисов. 2-е изд., доп. Москва: ИНФРА-М, 2010. 480 с. Текст: непосредственный.

11. Мюссе Л. Варварские нашествия на Европу: германский натиск. СанктПетербург: Евразия, 2006. 399 с. Текст: непосредственный.

12. Омельченко Е. А. Интеграция мигрантов средствами образования: российский и европейский опыт. Москва: Этносфера, 2018. 416 с. Текст: непосредственный.

13. Пирс К. Воины Китая. Под знаменем небесного дракона. 1500 г. до н. э. -1850 г. н. э. Москва: Эксмо, 2008. 248 с. Текст: непосредственный. 
14. Римский В. П. Демоны на перепутье: культурно-исторический образ тоталитаризма. Белгород: Изд-во Белгородского гос. ун-та, 1997. 199 с. Текст: непосредственный.

15. Рыбаков В. М. Танская бюрократия: в 2 частях. Ч. 1: Генезис и структура. СанктПетербург: Петербургское востоковедение, 2009. 512 с. Текст: непосредственный.

16. Сюаньлин Ф. Цзинь-шу // Материалы по истории кочевых народов в Китае III-V вв.: в 4 вып. Вып. 1. Сюнну. Москва: Наука, 1989. С. 29-162. Текст: непосредственный.

Статья поступила в редакцию 08.02.2021; одобрена после рецензирования 08.04.2021; принята к публикациии 11.05.2021.

\section{INTERACTION OF INTERNAL AND EXTERNAL BARBARISM \\ IN THE CRISIS OF CIVILIZATION}

\section{Stanislav I. Sulimov}

Cand. Sci. (Philos.), A/Prof.,

Voronezh State University

1 Universitetskaya Square, Voronezh 394018, Russia

sta-sulimov@ya.ru

\section{Igor V. Chernigovskikh}

Cand. Sci. (Philos.), A/Prof.,

Voronezh State University of Engineering Technologies

19 Revolutsii Prospect, Voronezh 394036, Russia

igrchernigovskix@rambler.ru

Abstract. The article analyzes the interaction of civilized and barbaric societies as an inevitable political and cultural process throughout world history. We believe that the technological and political level of development of a civilized society makes it invulnerable to external barbaric aggression as long as the spiritual unity of civilization is preserved. A spiritual crisis leads to the emergence and expansion of the ranks of internal barbarians - citizens who socially belong to civilization, but do not share its values. They make society defenseless against external enemies, since they use the political and economic mechanisms of civilization only for personal and particular purposes. We have defined the concepts of civilization and barbarism based on the studies of the Russian philosopher N. V. Motroshilova, and adopted factual material from the works of Western European and Eastern historians.

Keywords: civilization, barbarism, external and internal barbarians, spiritual crisis, counterculture, cultural apostasy, the Roman Empire, Imperial China, "The Arthaśāstra", the Dark Ages

\section{For citation}

Sulimov S. I., Chernigovskikh I. V. Interaction of Internal and External Barbarity in the Crisis of Civilization. Bulletin of Buryat State University. Philosophy. 2021; 2: 17-26 (In Russ.).

The article was submitted 08.02.2021; approved after reviewing 08.04.2021; accepted for publication 11.05.2021. 